\title{
Working with Nonprofit Organizations in Community Settings: Governance, Accountability and Transparency
}

Elizabeth B. Bolton and Anna Guest-Jelley

\section{Importance of Accountability and Transparency}

The Sarbanes-Oxley Act of July 30, 2002 is a federal law championed by the SEC (Securities and Exchange Commission) to regulate certain practices of publicly held companies. Although officially titled the Public Company Accounting Reform and Investor Protection Act, the legislation is more often referred to as SOX, an acronym of the names of the legislators who wrote it. Designed to restore confidence in corporate America following the financial scandals of Enron, Tyco, WorldCom, and others, it was intended for the for-profit sector; however, many of its provisions have major implications for the nonprofit sector and it is important to understand those that have specific application as well as what is meant by accountability and transparency.

There are eleven titles within the act, but six are of particular relevance for nonprofit boards. These six are excerpted and summarized from Jackson and Fogarty (2005, p. 7-12) as follows:

$\begin{array}{ll}\text { Title II } & \text { Auditor independence } \\ \text { Title III } & \text { Corporate responsibility } \\ \text { Title IV } & \text { Enhanced financial disclosures } \\ \text { Title VIII } & \begin{array}{l}\text { Corporate and criminal fraud accountability; document preservation and } \\ \text { whistleblower protection }\end{array} \\ \text { Title IX } & \text { White collar crime penalty } \\ \text { Title XI } & \text { Corporate fraud and accountability }\end{array}$

Title II gives the rules to establish independence of the auditor from the company being audited. It defines which additional services the auditing firm may and may not provide, defines and prohibits conflicts of interest between auditors and the audited company, requires the audited firm to rotate its auditors on regular basis, and requires the auditing committee of the audited company to be responsible for the oversight of its auditors.

1. This publication is FCS9246, one of a series of the Department of Family, Youth and Community Sciences, Florida Cooperative Extension Service, Institute of Food and Agricultural Sciences, University of Florida. First published: June 2009. Reviewed June 2012. Please visit the EDIS Web site at http://edis.ifas.ufl.edu.

2. Elizabeth B. Bolton, Ph.D., professor of Community Development, Department of Family, Youth and Community Sciences; Florida Cooperative Extension Service; Institute of Food and Agricultural Sciences; University of Florida; Gainesville, Florida 32611 - 0310; and, Anna Guest-Jelley, MFYCS, MA, director of Violence Prevention Program, Peaceful Paths Domestic Abuse Network, also of Gainesville, FL. 
Titles III and IV deal with the responsibilities and roles of the audited company and how this interacts with the audit company's role and the associated reports. Title III discusses corporate responsibility and the audit committee with specific information on the responsibility for financial reports. Specific suggestions are made concerning the improper influence on the conduct of the audit and the forfeiture of certain bonuses and profits. Title IV requires disclosure of periodic reports and a code of ethics for senior financial officers.

Title VIII addresses accountability, document preservation, and whistleblower protection. It protects employee informants and establishes responsibility for financial reports.

Title IX provides that each periodic report containing financial statements must be accompanied by a written statement by the issuer's CEO and CFO certifying that the report "fairly presents, in all material respects, the financial condition and results of the operations of the issuer."

Title XI prohibits retaliation against informants. This is a legal requirement for all organizations, whether forprofit or nonprofit.

\section{Main Provisions of the Sarbanes-Oxley Act}

The main provisions of the Sarbanes-Oxley Act given below are excerpted and summarized with permission from BoardSource and Independent Sector (2006).

\section{Independent and Competent Audit Committee}

\section{Summary of Sarbanes-Oxley Provision}

- Requires that each member of a company's audit committee be a member of the board of directors and be independent.

Relevance to Nonprofit Boards

- Nonprofit organizations need to ensure that board members on the audit committee have the financial competency to understand financial statements, evaluate accounting company bids to undertake auditing, and make sound decisions as part of their fiduciary responsibilities.

\section{Recommendations}

- While there are no standard guidelines mandating when a nonprofit organization should undertake an audit, the board is responsible for assessing potential benefits and costs.

\section{Responsibilities of Auditors}

\section{Summary of Sarbanes-Oxley Provisions}

- Requires that the lead and reviewing partner of the auditing firm rotate off of the audit every five years. Relevance to Nonprofit Boards

- Changing auditors every five years is considered good practice for all organizations, nonprofit and forprofit alike.

\section{Recommendations}

- Nonprofits should be cautious when using their auditing firms to provide non-auditing services except for tax preparation, the action of which should be approved in advance. 


\section{Certified Financial Statements}

Summary of Sarbanes-Oxley Provisions

- The chief executive and the chief financial officers must certify that the financial statements are appropriate and that they fairly present the financial conditions and operations of the company.

Relevance to Nonprofit Corporations

- It is important that Chief Executive Officers (CEOs) and/or Chief Financial Officers (CFOs) understand their respective organization's financial statements.

\section{Recommendations}

- Even though CEOs and CFOs do not have to sign-off on financial statements, they need to understand the reports and make sure they are accurate and complete.

- The board has the ultimate fiduciary responsibility for approving financial reports. Both the audit report and the organization's Form 990 or 990-PF should be reviewed and approved by the audit committee and the board.

\section{Insider Trading and Conflicts of Interest}

Summary of Sarbanes-Oxley Provision

- The Act generally prohibits loans to any directors or executives of a for-profit company.

Relevance to Nonprofit Organizations

- Nonprofits are highly regulated with respect to transactions that take place within the organization.

- In some states, nonprofit law expressly prohibits loans to directors and officers.

Recommendations

- Because the practice of providing loans to nonprofit organizations has been a source of trouble and is strictly prohibited in some states, it is strongly recommended that nonprofit organizations refrain from providing personal loans to directors or executives.

\section{Disclosure}

Summary of Sarbanes-Oxley Provision

- In for-profit companies, the Sarbanes-Oxley Act requires a number of disclosures, including:

0 information on internal control mechanisms,

o corrections to past financial statements

0 material off-balance sheet transactions (adjustments), and

0 disclosure of information on material changes in operations or financial situation of the company on a rapid or current basis.

Relevance to nonprofit organizations

- While many of the disclosure transactions required for publicly traded companies do not apply to nonprofit organizations, an accurate picture of a nonprofit's financial condition should be provided for:

0 donors, clients, public officials, the media, and others.

\section{Recommendations}

- At the board's discretion, Forms 990 and 990-PF may be electronically uploaded to GuideStar ${ }^{\circledR}$ at www2.guidestar.org for complete transparency with your present and future stakeholders.

*The following two provisions of the Sarbanes-Oxley Act apply to both for-profit and nonprofit organizations. All nonprofit organizations need to understand these provisions and comply with them. 


\section{Whistle-blower Protection}

\section{Summary of Sarbanes-Oxley Provision}

- The Act provides new protections for whistle-blowers who risk their careers by reporting suspected illegal activities within the organization. It is illegal for both for-profit and nonprofit entities to punish a whistle-blower in any manner. There are criminal penalties for actions taken in retaliation.

Relevance for Nonprofit Organizations

- In order to protect themselves, nonprofits must eliminate careless and irresponsible accounting practices.

o An internal audit that brings weak spots to light and results in the installation of processes that are not vulnerable to fraud and abuse would be very beneficial.

o Vigorously enforced written policies send a message that misconduct is not tolerated.

\section{Recommendations}

- Nonprofits must develop, adopt, and disclose a formal process to deal with complaints and prevent retaliation.

- Employee complaints must be taken seriously, investigated, corrected if legitimate, or justified as to why corrections are considered unnecessary.

\section{Document Destruction}

Summary of Sarbanes-Oxley Provision

- The Sarbanes-Oxley Act addresses destruction of litigation-related documents.

- The law makes it a crime to alter, cover up, falsify, or destroy any document to prevent its use in an official proceeding (e.g., federal investigation or bankruptcy proceedings).

- The Act turns intentional document destruction into a process that must be monitored, justified, and carefully administered.

Relevance to Nonprofit Organizations

- Nonprofit corporations need to maintain appropriate records about their operations.

o Financial records, significant contracts, real estate and other major transactions, employment files, and fundraising obligations should be archived according to guidelines established by the organization.

\section{Recommendations}

- Nonprofits should have and follow a written, mandatory document retention and periodic destruction policy.

\section{References}

BoardSource and Independent Sector (2006). The Sarbanes-Oxley act and implications for nonprofit organizations. Retrieved electronically on July 14, 2006 from http://www.independentsector.org/issues/SarbanesOxley.html.

Jackson, P.M. and Fogarty, T.E. (2005). Sarbanes-Oxley for nonprofits: A guide to building competitive advantage. Hoboken, N.J.: John Wiley and Sons. (p. 7-12). 